\title{
Inhibition of methane hydrate nucleation and growth by an antifreeze protein
}

Mu, Liang; Ramløv, Hans; Søgaard, T. Max M.; Jørgensen, Thomas; de Jongh, Willem A.; von Solms, Nicolas

Published in:

Journal of Petroleum Science and Engineering

Link to article, DOI:

10.1016/j.petrol.2019.106388

Publication date:

2019

Document Version

Peer reviewed version

Link back to DTU Orbit

Citation (APA):

Mu, L., Ramløv, H., Søgaard, T. M. M., Jørgensen, T., de Jongh, W. A., \& von Solms, N. (2019). Inhibition of methane hydrate nucleation and growth by an antifreeze protein. Journal of Petroleum Science and Engineering, 183, [106388]. https://doi.org/10.1016/j.petrol.2019.106388

\section{General rights}

Copyright and moral rights for the publications made accessible in the public portal are retained by the authors and/or other copyright owners and it is a condition of accessing publications that users recognise and abide by the legal requirements associated with these rights.

- Users may download and print one copy of any publication from the public portal for the purpose of private study or research.

- You may not further distribute the material or use it for any profit-making activity or commercial gain

- You may freely distribute the URL identifying the publication in the public portal 


\section{Journal Pre-proof}

Inhibition of methane hydrate nucleation and growth by an antifreeze protein

Liang Mu, Hans Ramløv, T. Max M. Søgaard, Thomas Jørgensen, Willem A. de Jongh, Nicolas von Solms

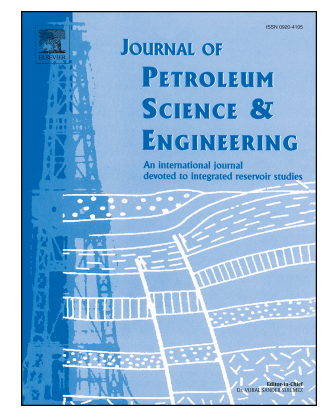

PII:

S0920-4105(19)30809-5

DOI: https://doi.org/10.1016/j.petrol.2019.106388

Reference: PETROL 106388

To appear in: Journal of Petroleum Science and Engineering

Received Date: 22 February 2019

Revised Date: 13 August 2019

Accepted Date: 14 August 2019

Please cite this article as: Mu, L., Ramløv, H., Søgaard, T.M.M., Jørgensen, T., de Jongh, W.A., von Solms, N., Inhibition of methane hydrate nucleation and growth by an antifreeze protein, Journal of Petroleum Science and Engineering (2019), doi: https://doi.org/10.1016/j.petrol.2019.106388.

This is a PDF file of an article that has undergone enhancements after acceptance, such as the addition of a cover page and metadata, and formatting for readability, but it is not yet the definitive version of record. This version will undergo additional copyediting, typesetting and review before it is published in its final form, but we are providing this version to give early visibility of the article. Please note that, during the production process, errors may be discovered which could affect the content, and all legal disclaimers that apply to the journal pertain.

(c) 2019 Published by Elsevier B.V. 


\title{
Inhibition of methane hydrate nucleation and growth by an antifreeze protein
}

Liang Mu, ${ }^{\dagger}$ Hans Ramløv, ${ }^{\ddagger}$ T. Max M. Søgaard, ${ }^{\S}$ Thomas Jørgensen,,${ }^{\S}$ Willem A. de Jongh, ${ }^{\S}$ and Nicolas von Solms ${ }^{* \dagger}$

${ }^{\dagger}$ Department of Chemical and Biochemical Engineering, Center for Energy Resource Engineering (CERE), Technical University of Denmark, DK-2800 Kgs. Lyngby, Denmark

${ }^{\ddagger}$ Department of Science and Environment, Roskilde University, DK-4000 Roskilde, Denmark

${ }^{\S}$ ExpreS ${ }^{2}$ ion Biotechnologies, Agern Allé 1, Hørsholm, 2970, Denmark

\begin{abstract}
Antifreeze proteins (AFPs) are characterized by their ability to protect organisms from subfreezing temperatures. They constitute a class of promising candidates as environmentally kinetic hydrate inhibitors (KHIs). In this study, the effectiveness of an insect cell expressed novel monomeric streptavidin fusion protein version of Rhagium mordax RmAFP1 antifreeze protein (mSA-RmAFP1), and four amino acids (histidine, lysine, tyrosine and proline), on $\mathrm{CH}_{4}$ hydrate nucleation, growth and decomposition was investigated using a rocking cell apparatus, then compared with the commercial inhibitors Polyvinylpyrrolidone (PVP) and Luvicap Bio. It was found that $\mathrm{CH}_{4}$ hydrate nucleation and growth exhibited good repeatable results under experimental conditions. The results showed that 2250 ppm mSA-RmAFP1 can inhibit $\mathrm{CH}_{4}$ hydrate nucleation as effectively as PVP at the same concentration. The histidine, lysine, tyrosine and proline exhibited weak inhibition effect on $\mathrm{CH}_{4}$ hydrate nucleation. The mSA-RmAFP1 decreased $\mathrm{CH}_{4}$ hydrate growth rate and production in the fresh and memory solutions. The $\mathrm{CH}_{4}$ hydrate formed in the

\footnotetext{
${ }^{*}$ Corresponding Author.

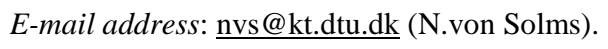


solutions containing various tested KHIs present slightly lower onset decomposition temperatures than the non-inhibited system under experimental conditions. The promising performance of the insect cell expressed mSA-RmAFP1 could promote the further development of green hydrate inhibitors. The production of this protein through insect cell line fermentation provides a platform for the future production and optimization of AFPs for hydrate inhibition.

Keywords: Hydrate nucleation, Inhibition, Antifreeze Protein, Environment friendly

\section{Introduction}

Gas hydrates are ice-like crystalline compounds composed of cages formed by hydrogen-bonded water molecules which encapsulate suitable-sized guest molecules under high pressure and low temperature conditions (Sloan and Koh, 2008; Englezos, 1993). In the process of oil and gas production and transportation, natural gas hydrate formation raised flow assurance challenges because they often block pipelines and cause serious safety issues and economic loss (Hammerschmidt, 1934; May et al., 2014; Koh et al., 2002; Perrin et al., 2013). The conventional method of using thermodynamic hydrate inhibitors (THIs) has become an environmental concern, because most of them (such as methanol and glycols) are toxic (Koh, 2002; Kelland, 2006; Englezos, 1996). In addition, the economics of THIs are no longer attractive due to the huge amount of usage (>50 vol\%), especially in deep water and high subcooling conditions. An alternative method is adding kinetic hydrate inhibitors (KHIs) at much lower concentrations (0.1-1.0 wt\%). Most KHIs are synthetic polymers compounds which can delay hydrate nucleation within a certain time to ensure the flow safety (Cohen et al., 1998; Yang and Tohidi, 2005; Duchateau et al., 2009; Kelland et al., 2008). Although KHIs are effective at very low concentrations, most of them are restricted because of the poor biodegradability, which motivates us to search for environment friendly hydrate inhibitors (Villano et al., 2008). While hydrates formed in natural gas recovery 
processes will be of type structure II, it is also of interest to investigate the inhibition of structure I hydrate, since the vast amount of naturally occurring hydrates are structure I. Any process where gas is recovered from these deposits will benefit from knowledge of the decomposition and inhibition behavior of these hydrates.

Antifreeze proteins (AFPs) as a kind of biological hydrate inhibitors have been widely reported by many researchers in recent years (Jensen et al., 2011; Zeng et al., 2006a; Al-Adel et al., 2008; Perfeldt et al., 2014; Daraboina et al., 2015), they mainly exist in various organisms living in high latitude regions, such as plants, fish and insects (Duman and Olsen, 1993; Duman et al., 2004; Raymond and Devries, 1977). AFPs are a group of proteins that can protect organisms from freezing at subfreezing temperatures by a non-colligative process. Zeng et al. (2003) studied the effect of AFP from the winter flounder on the tetrahydrofuran (THF) hydrate formation, they found that AFP can retard THF hydrate growth and change the crystal morphology from octahedral to plate-like. Subsequently, Zeng et al. (2006b) further investigated the effect of AFP on the formation of $\mathrm{C}_{3} \mathrm{H}_{8}$ and $\mathrm{CH}_{4}$ hydrates. The results showed that the formation of these two hydrates can be significantly inhibited. In addition, they believed the AFP can eliminate the hydrate memory effect. Jensen et al. (2010) tested the influence of ice-structuring protein (ISP) type III HPLC12 (originally identified in ocean pout (Macrozoarces americanus)) and TmAFP from the meal worm (Tenebrio molitor) on $\mathrm{CH}_{4}$ hydrate formation. They reported that ISP type III HPLC12 decreased the growth rate of $\mathrm{CH}_{4}$ hydrate by $17-75 \%$ at concentrations of $0.01-0.1 \mathrm{wt} \%$, TmAFP and PVP decreased the growth rate by $30 \%$ and $39 \%$ at concentrations of 0.004 wt $\%$ and 0.1 wt $\%$, respectively. Daraboina et al. (2011a,b,c; 2013a) used multiple methods to investigate the effectiveness of two fish AFPs: type I AFP (3.3-4.5 kDa) and type III AFP $(7 \mathrm{kDa})$ on $\left(\mathrm{CH}_{4}+\mathrm{C}_{2} \mathrm{H}_{6}+\mathrm{C}_{3} \mathrm{H}_{8}\right)$ mixed hydrates formation and decomposition, their results showed that these proteins have distinct inhibition activity. Perfeldt et al. (2014) investigated the performance of AFP from the longhorn 
beetle, Rhagium mordax (RmAFP1), on $\mathrm{CH}_{4}$ hydrate formation. They reported that RmAFP1 (2770 ppm) can inhibit hydrate nucleation as effectively as PVP in both fresh and memory solutions (which are the solutions experienced hydrate formation and decomposition and have memory effect). Ohno et al. (2010) tested four AFPs with gas uptake and differential scanning calorimetry (DSC) method, including a low thermal hysteresis (TH) LpAFP-GFP (TH=0.10 $\left.{ }^{\circ} \mathrm{C}, 41 \mathrm{kDa}\right)$, a moderately active ocean pout type III AFP $\left(\mathrm{TH}=0.43^{\circ} \mathrm{C}, 6.8 \mathrm{kDa}\right)$, and a type III AFP-GFP $\left(\mathrm{TH}=0.48^{\circ} \mathrm{C}, 32 \mathrm{kDa}\right)$, as well as a hyperactive TmAFP $\left(\mathrm{TH}=3.5^{\circ} \mathrm{C}, 8.4 \mathrm{kDa}\right)$. It was found that the four AFPs can delay the induction period remarkably. Subsequently, Ohno et al. (2012) investigated the $\left(\mathrm{CH}_{4}+\mathrm{C}_{2} \mathrm{H}_{6}+\mathrm{C}_{3} \mathrm{H}_{8}\right)$ hydrate structure in the presence of type III AFP and LpAFP-GFP with ${ }^{13} \mathrm{C}$ NMR and in situ PXRD. Their results indicated these two AFPs could affect the kinetics of cavity formation.

From the above reports it can be seen that AFPs from different species have the ability to inhibit hydrate formation. Therefore, they have attracted the attention of many researchers. The hydrate nucleation phenomenon is random in most cases, repeatable experiments and statistical analysis are important to understand the performance of inhibitors. Zeng et al. (2003, 2006b) used multiple measurements for statistical purposes, 50 parallel experiments were conducted and 12 samples at a time were imaged by ${ }^{1} \mathrm{H}$ NMR microscopy. Ohno et al. (2010) tested 12 samples at a time to obtain nucleation statistics with DSC method. In this work, the rocking cell apparatus with five units was used to test inhibitors, which can provide statistical results under the same conditions. Considering that the composition of natural gas is complicated, its components and phase equilibrium boundary will be changed in the hydrate formation. Therefore, pure $\mathrm{CH}_{4}$ was used as hydrate former in this study. The performance of a kind of new AFPs (mSA-RmAFP1) was investigated then compared with commercial inhibitors. The sequence of mSA-RmAFP1 was based on the known sequence of RmAFP1, which has high antifreeze activity over $8{ }^{\circ} \mathrm{C}$ (Wilkens and Ramlov, 2008). Part of the 
novelty of this work is the testing with a protein (mSA-RmAFP1) from an insect cell line, whereas the RmAFP1 (Perfeldt et al., 2014) was with a bacterial fermentation. It was reported that the repeats of a motif rich in the threonine (TxTxTxT-motifs) make up the ice-binding site (Kristiansen et al., 2012). However, the threonine did not present KHI effect by itself in the work of Perfeldt et al. (2014). The proteins consist of polymers of amino acids. To seek the monomer with better performance used for synthesizing new biological KHIs, four other amino acids were examined in this work. The results are expected to provide an essential research information to develop new environment friendly hydrate inhibitors.

\section{Experimental section}

\subsection{Materials}

$\mathrm{CH}_{4}$ (99.995 mol\%) was supplied by AGA company, Milli-Q water was used to prepare all solutions. PVP $\left(\mathrm{M}_{\mathrm{W}}=10 \mathrm{kDa}\right)$ was purchased from Sigma-Aldrich. Luvicap Bio was provided by BASF, which is a commercial inhibitor developed base on the polymer PVCap but has a higher biodegradability. Histidine (purity $\geq 99.0 \%$ ), lysine (purity $\geq 98.0 \%$ ), tyrosine (purity $\geq 98.0 \%$ ) and proline (purity $\geq 99.0 \%$ ) were supplied from Sigma-Aldrich.

The AFP sequence was based on the known sequence of antifreeze protein from the bark beetle Rhagium mordax (RmAFP1) (Kristiansen et al., 2012). To increase AFP expression levels, monomeric streptavidin (mSA) (Demonte et al., 2014) was genetically fused to the N-terminal of RmAFP1. The protein additionally encoded a BiP secretion signal to enable secretion of the mSARmAFP1 into the cell supernatant. DNA encoding the fusion protein was inserted into the EcoRINotI sites of the pExpres2-1 vector (ExpreS2ion Biotechnologies, Hørsholm, Denmark) and transfected into Drosophila melanogaster S2 cells to create stably integrated polyclonal cell pool. 
The creation of a stable polyclonal cell line was as described by Hjerrild et al. (2016). AFP was purified at ExprS2ion Biotechnologies from 2 liters of supernatant. Ultrafiltration using a Tangential flow filtration device (TangenX) equipped with a $10 \mathrm{KDa}$ MWCO filter (Pall) concentrated the supernatant by 15 fold and diafiltration (10 turn-over-volumes) using the same device exchanged the buffer to $\mathrm{C}$ tag capture buffer (50 mM TrisHCl, $150 \mathrm{mM} \mathrm{NaCl}$, $\mathrm{pH} 7.0$ ). Following C-tag capture and washing to OD280nm baseline in the same buffer the mSA-AFP protein eluted in $50 \mathrm{mM}$ TrisCl $2 \mathrm{M} \mathrm{MgCl}_{2} \mathrm{pH}$ 7.0. Peak fractions were pooled and buffer exchanged into $50 \mathrm{mM}$ TrisCl, $200 \mathrm{mM} \mathrm{NaCl} \mathrm{pH} 7.0$ by HiPrep2610 (GE) size exclusion chromatography. The mSA-RmAFP1 has a molecular weight of $25.66 \mathrm{kDa}$, and was stored at -80 ${ }^{\circ} \mathrm{C}$ until use. The purified yield was $60 \mathrm{mg} / \mathrm{L}$ supernatant.

\subsection{Experimental Apparatus}

The rocking cell apparatus (RC-5) was used to test the performance of KHIs (Fig. 1). It has five stainless steel cells installed in a cooling bath which can be operated between -20 60 ${ }^{\circ} \mathrm{C}$. The effective volume of each cell is $40 \mathrm{~mL}$ and their working pressure can be up to 200 bar. The cells can be rocked within the angle of $-45 \sim 45^{\circ}$, a stainless steel ball inside each cell can roll and agitate the solution. The main purpose of this study is to measure the onset hydrate nucleation temperature by rocking the cells at constant cooling rate. The performance of KHIs can be obtained by comparing the onset temperature of the inhibited system with that of the non-inhibited system. The detailed description of this setup can be referred to in our previous work (Daraboina et al., $2013 b, c, d)$. 


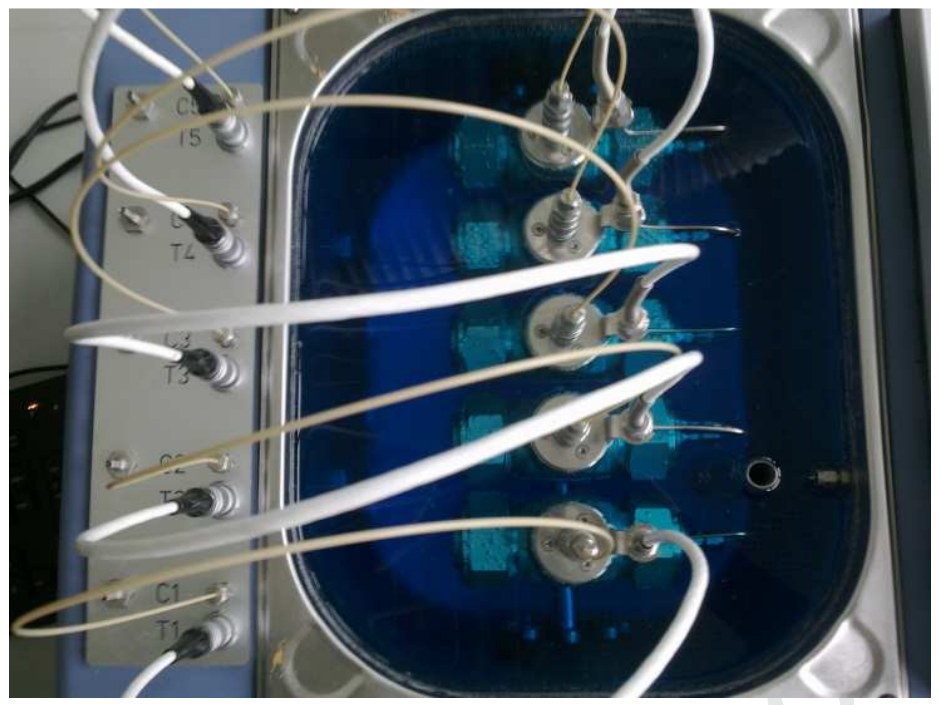

Fig. 1. Rocking cell apparatus used in this work.

\subsection{Experimental Procedure}

First, the cells were cleaned with acetone and distilled water then dried with air flow. Each cell was loaded with $10 \mathrm{~mL}$ solution then installed in the apparatus. To expel air from the cells and tubes, they were evacuated using a vacuum pump for 3 minutes. Subsequently, the cells were pressurized with $\mathrm{CH}_{4}$ to 95 bar and set to rock at 20 rocks $/ \mathrm{min}$ at an angle of $40^{\circ}$. The equilibrium temperature for $\mathrm{CH}_{4}$ hydrate in pure water system is $12.5{ }^{\circ} \mathrm{C}$, which was calculated by CSMGem model (Sloan and Koh, 2008). The temperature program was performed as follows: first cooling from 20.5 to $2.0{ }^{\circ} \mathrm{C}$ at $0.1{ }^{\circ} \mathrm{C} / \mathrm{min}$, then heating from 2.0 to $20.5^{\circ} \mathrm{C}$ at $0.5^{\circ} \mathrm{C} / \mathrm{min}$. A typical pressuretemperature changes is shown in Fig. 2. The onset nucleation and decomposition temperatures $\left(T_{\mathrm{on}}\right.$ and $\left.T_{\text {od }}\right)$ can be identified on the basis of sudden changes in the pressure curves. For the statistical results, each inhibitor was tested 5 times under the same conditions. The detailed experimental procedures can be found elsewhere (Daraboina et al., 2013b,c,d). 


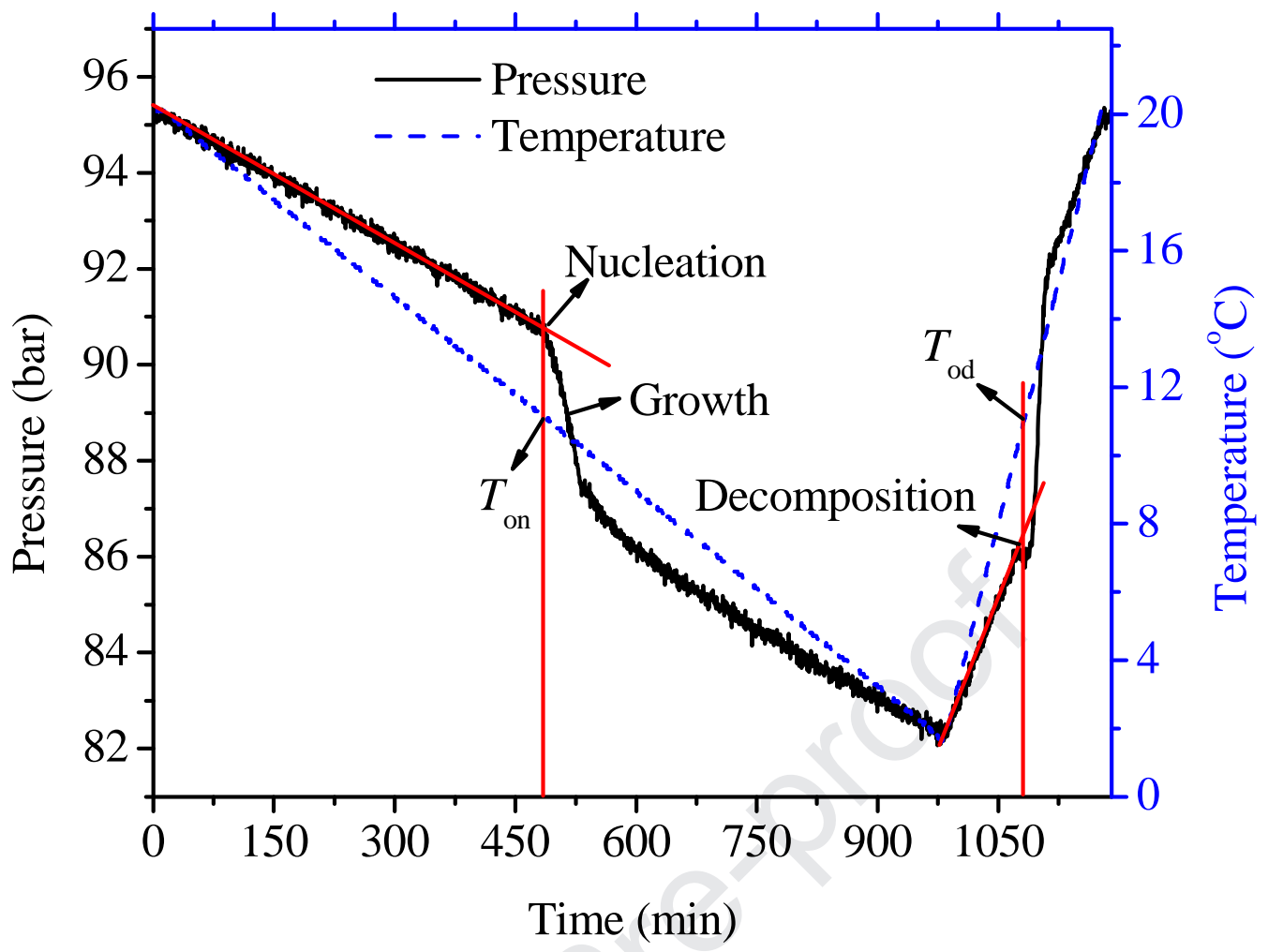

Fig. 2. Typical pressure and temperature curves in one test.

\section{Results and discussion}

\subsection{The onset nucleation temperatures of $\mathrm{CH}_{4}$ hydrate}

The performance of various chemicals was evaluated by comparing the onset hydrate nucleation temperatures of inhibited systems with that of non-inhibited system (Milli-Q water). The test results for fresh and memory solutions are summarized in Tables 1 and 2, respectively. It can be seen that the relative standard deviation was between $0.90 \sim 4.17 \%$ (standard deviation 0.07 0.40 ${ }^{\circ} \mathrm{C}$ ), which shows good repeatability of the tests. The number of tests was discrepant because the mSARmAFP1 is available in limited quantities. For the fresh solutions in the presence of histidine, lysine, tyrosine and proline, the onset nucleation temperatures of $\mathrm{CH}_{4}$ hydrate are $10.3,10.1,10.7$ and $10.5^{\circ} \mathrm{C}$, respectively. The results suggest that the four amino acids have weak inhibition effect. 
Edwards et al. (1994a,b) investigated all natural amino acids in the early 1990's, they patented tyrosine but dropped all work shortly after due to their very poor KHI effect. After that they moved on to better KHIs such as PVP, PVCap etc. From Table 1, it can be seen that 2250 ppm mSARmAFP1 decreased the onset hydrate nucleation temperature from 11.8 to $7.8^{\circ} \mathrm{C}$, which performed as effectively as PVP $\left(7.9^{\circ} \mathrm{C}\right)$ at the same concentration. However, the advantage of mSA-RmAFP1 is that it is a potentially environmentally friendly inhibitor, and the results are promising enough to suggest further research is worthwhile. $850 \mathrm{ppm}$ mSA-RmAFP1 $\left(9.2^{\circ} \mathrm{C}\right)$ showed poorer inhibition activity than PVP $\left(8.9^{\circ} \mathrm{C}\right)$ but better than Luvicap Bio $\left(9.6^{\circ} \mathrm{C}\right)$, the reason might be that the mSARmAFP1 at a concentration of $850 \mathrm{ppm}$ is too low to efficiently inhibit $\mathrm{CH}_{4}$ hydrate nucleation. The average onset hydrate nucleation temperatures for fresh solution are as follows: 1,2250 ppm: mSA$\operatorname{RmAFP} 1\left(7.8^{\circ} \mathrm{C}\right)<\operatorname{PVP}\left(7.9^{\circ} \mathrm{C}\right)<\operatorname{Luvicap} \operatorname{Bio}\left(8.4^{\circ} \mathrm{C}\right)<\operatorname{lysine}\left(10.1^{\circ} \mathrm{C}\right)<\operatorname{histidine}\left(10.3^{\circ} \mathrm{C}\right)<$ proline $\left(10.5^{\circ} \mathrm{C}\right)<\operatorname{tyrosine}\left(10.7^{\circ} \mathrm{C}\right)<$ Milli-Q water $\left(11.8^{\circ} \mathrm{C}\right) ; 2,850$ ppm: PVP $\left(8.7{ }^{\circ} \mathrm{C}\right)<\mathrm{mSA}$ RmAFP1 $\left(9.2{ }^{\circ} \mathrm{C}\right)<$ Luvicap Bio $\left(9.5{ }^{\circ} \mathrm{C}\right)<$ Milli-Q water $\left(11.8^{\circ} \mathrm{C}\right)$. The memory solutions (Table 2) are investigated to test the influence of various KHIs on the hydrate memory effect (Buchanan et al., 2005). The onset formation temperatures for fresh and memory solution are shown in Figs. 3 and 4, respectively. Given the standard deviations observed and only one test in the fresh mSARmAFP1 solution was conducted, it cannot be concluded that the mSA-RmAFP1 memory solutions gave higher onset hydrate nucleation values or the mSA-RmAFP1 eliminated the memory effect. To further investigate the influence of mSA-RmAFP1 on the memory effect, the induction time measurement under isothermal conditions would be conducted in the future. With respect to the inhibition mechanism of AFP, it is still unclear how it controls the hydrate nucleation rate. Zeng et al. (2006b) proposed that AFPs can adsorb on the hydrophilic surface to form a rigid film, which affects the hydrate nucleation and growth. They believed this ability distinguishes AFPs from synthetic KHIs (such as PVP and PVCap). Bagherzadeh et al. (2015) studied the inhibition 
mechanism of the wf-AFP (a kind of AFPs originated from winter flounder) with molecular dynamics (MD) simulations. It was found that wf-AFP can adhere to the specific plane of $\mathrm{CH}_{4}$ hydrate, then cover the hydrate surface and increase mass transfer resistance of $\mathrm{CH}_{4}$ and $\mathrm{H}_{2} \mathrm{O}$ molecules. They believed that the pendant methyl groups in AFPs play a key role in the inhibition hydrate nucleation. Yagasaki et al. (2018, 2015) found that PVCap can adsorb on various crystallographic planes of sI and sII hydrate by MD simulations. They thought the hydrophobic groups of a polymer are more helpful to their adsorption to the hydrate cage structure than the isolated monomer. If so, the performance of KHIs would depend on the degree of polymerization to some extent. Haymet et al. (1999) reported that the hydrophobic methyl group in threonine significantly contribute to the antifreeze activity of AFPs. The molecular weight of mSA-RmAFP1 and PVP in this study are 25.66 and $10 \mathrm{kDa}$, respectively. In addition, the molecular weight of RmAFP1 used in our previously work was $13.9 \mathrm{kDa}$ (Perfeldt et al., 2014). Based on our current research, it's hard to establish the similar sized molecular entities acting on the hydrate. However, these findings might provide some insights in seeking more effective biological KHIs.

Table 1. Test results for the fresh solutions.

\begin{tabular}{cccccc}
\hline Fresh solution & Number of tests & Concentration $(\mathrm{ppm})$ & $T_{\text {on }}\left({ }^{\circ} \mathrm{C}\right)$ & $\mathrm{SD}\left({ }^{\circ} \mathrm{C}\right)$ & $\mathrm{RSD}(\%)$ \\
\hline Milli-Q & 5 & - & 11.8 & 0.39 & 3.31 \\
histidine & 5 & 2250 & 10.3 & 0.37 & 3.59 \\
lysine & 5 & 2250 & 10.1 & 0.35 & 3.47 \\
tyrosine & 5 & 2250 & 10.7 & 0.23 & 2.15 \\
proline & 5 & 2250 & 10.5 & 0.40 & 3.81 \\
mSA-RmAFP1 & 1 & 850 & 9.2 & - & - \\
& 1 & 2250 & 7.8 & - & - \\
PVP & 15 & 850 & 8.7 & 0.27 & 3.10 \\
& 15 & 2250 & 7.9 & 0.26 & 3.29 \\
Luvicap Bio & 15 & 850 & 9.5 & 0.31 & 3.26 \\
& 15 & 2250 & 8.4 & 0.35 & 4.17 \\
\hline
\end{tabular}

${ }^{*} T_{\mathrm{on}}$ is the onset nucleation temperature, SD is standard deviation, RSD is the relative standard deviation.

Table 2. Test results for the memory solutions. 


\begin{tabular}{cccccc}
\hline Memory solution & Number of tests & Concentration $(\mathrm{ppm})$ & $T_{\text {on }}\left({ }^{\circ} \mathrm{C}\right)$ & $\mathrm{SD}\left({ }^{\circ} \mathrm{C}\right)$ & $\mathrm{RSD}(\%)$ \\
\hline Milli-Q & 5 & - & 11.9 & 0.33 & 2.77 \\
histidine & 5 & 2250 & 10.4 & 0.38 & 3.65 \\
lysine & 5 & 2250 & 10.3 & 0.31 & 3.01 \\
tyrosine & 5 & 2250 & 10.8 & 0.27 & 2.50 \\
proline & 5 & 2250 & 10.6 & 0.36 & 3.40 \\
mSA-RmAFP1 & 5 & 850 & 9.3 & 0.23 & 2.47 \\
& 5 & 2250 & 7.9 & 0.07 & 0.90 \\
PVP & 15 & 850 & 8.9 & 0.27 & 3.03 \\
& 15 & 2250 & 8.0 & 0.28 & 3.50 \\
Luvicap Bio & 15 & 850 & 9.6 & 0.38 & 3.96 \\
& 15 & 2250 & 8.6 & 0.29 & 3.37 \\
\hline
\end{tabular}

${ }^{*} T_{\mathrm{on}}$ is the onset nucleation temperature, SD is standard deviation, RSD is the relative standard deviation.

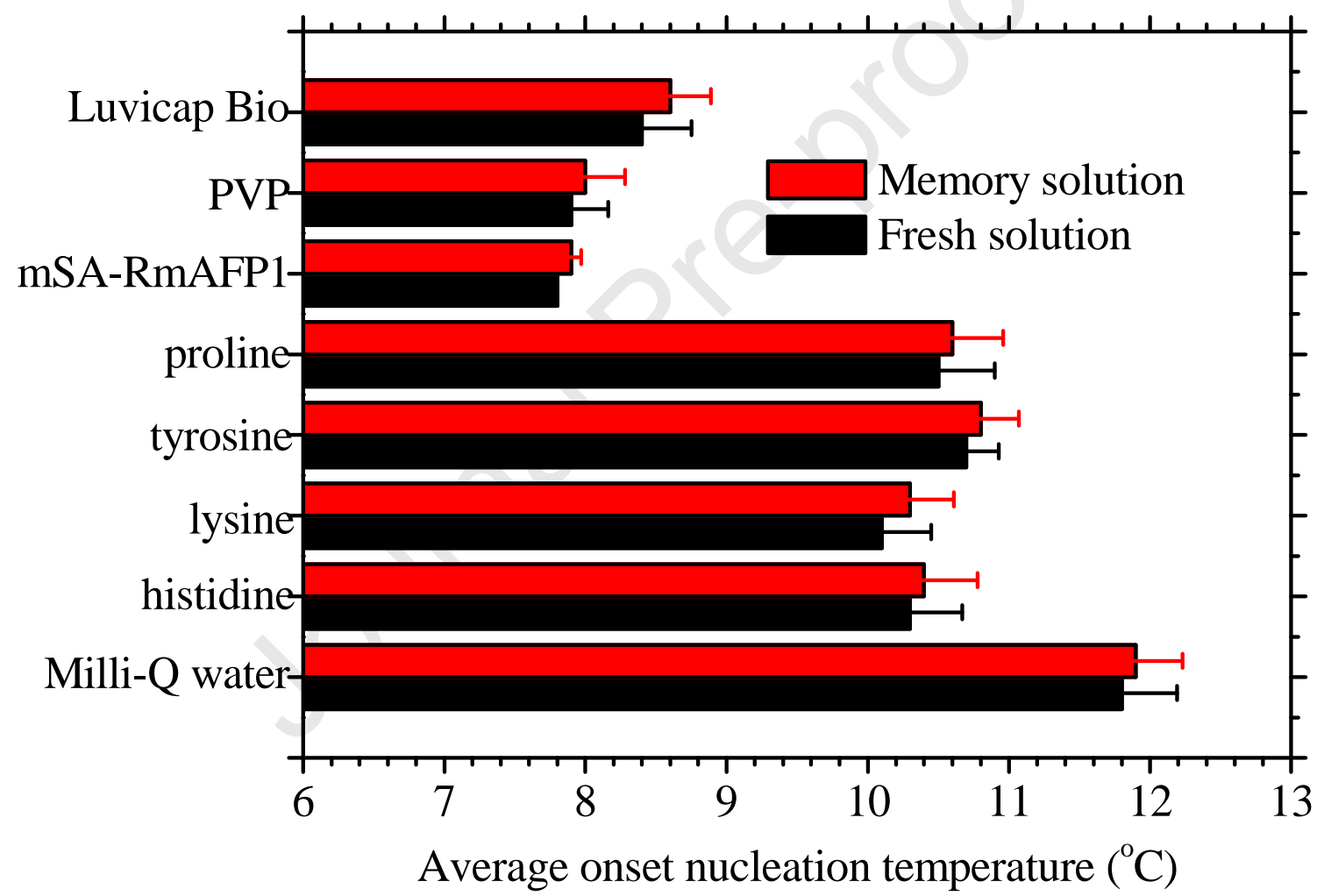

Fig. 3. The onset nucleation temperatures for the fresh and memory solutions containing $2250 \mathrm{ppm}$ inhibitors (error bars represent standard deviations). 


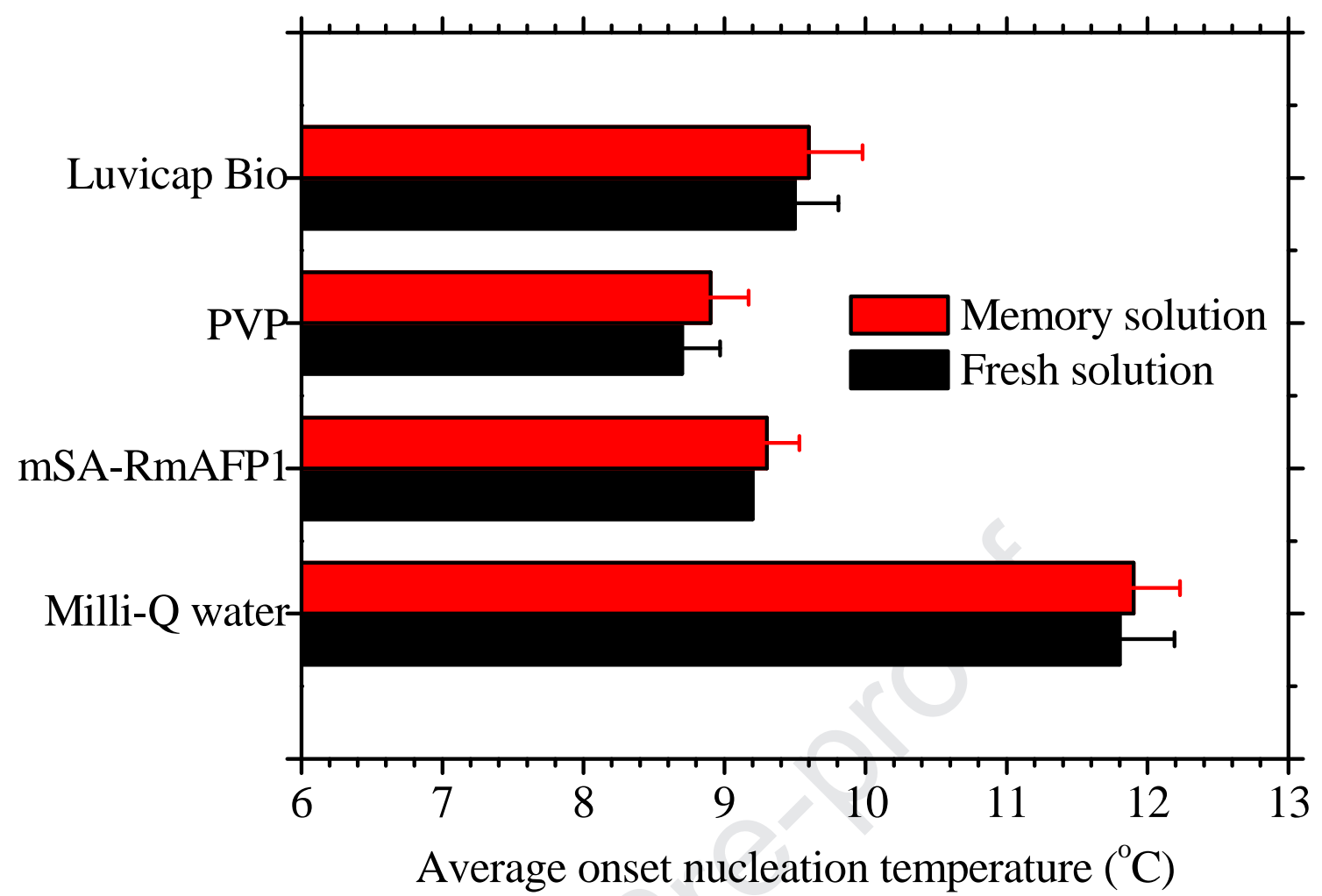

Fig. 4. The onset nucleation temperatures for the fresh and memory solutions containing $850 \mathrm{ppm}$ inhibitors (error bars represent standard deviations).

\section{2. $\mathrm{CH}_{4}$ hydrate crystal growth}

Al-Adel et al. (2008) performed kinetic experiments on $\left(\mathrm{CH}_{4}+\mathrm{H}_{2} \mathrm{O}\right)$ system in the presence of Type-I AFP, they believed that AFPs can act as hydrate inhibitor or promoter, mainly depending on the temperature and pressure conditions. In this work, $\mathrm{CH}_{4}$ hydrate crystal growth curves for the mSA-RmAFP1 fresh and memory solutions are investigated and shown in Fig. 5. It can be seen that the pressure changes have the same trend, which indicates the hydrate crystal growth process can also be repeated in the rocking cells but not the onset nucleation temperature. It should be noted that the repeatability is dependent on the subcooling being the same at the onset of hydrate formation. In addition, it was found that $\mathrm{CH}_{4}$ hydrate growth rate and production in the mSA-RmAFP1 solutions are significantly different from the non-inhibited system. In order to compare the hydrate growth for 
different systems, pressure changes starting from the onset nucleation temperature are normalized and shown in Figs. 6 and 7, respectively. The pressure drops are indicative of hydrate production, and the hydrate growth rate can be identified by the slope of pressure changes. For the fresh solutions (Fig. 6), the mSA-RmAFP1 system showed the lowest hydrate production (pressure drop of $6.74 \%$ ), which is lower than the non-inhibited system $(8.18 \%)$. The two highest pressure drops are observed in PVP (12.72\%) and histidine (13.56\%) solutions. The reason might be that PVP and histidine increased the reaction area of hydrate nucleation, which leads to more $\mathrm{CH}_{4}$ molecules can be captured by hydrogen-bonded water molecules. In addition, the two solutions present faster crystal growth rate, which indicates that PVP and histidine promoted hydrate growth although they can delay nucleation. Some researchers reported that once hydrates are formed in the presence of inhibitors, the hydrate growth can be promoted compared to a non-inhibited system (Daraboina et al., 2013b; Lederhos et al., 1996). The tyrosine and proline fresh solutions showed similar growth rate and hydrate production $(8.30 \%$ and $8.13 \%$, respectively). For the memory solutions (Fig. 7), Milli-Q water present the highest pressure drop (14.31\%), the reason might be the memory effect promoted $\mathrm{CH}_{4}$ hydrate grow. The mSA-RmAFP1 and Luvicap Bio showed a lower hydrate growth rate and their pressure drops are $6.96 \%$ and $7.30 \%$, respectively. By analyzing the results, it can be seen that the mSA-RmAFP1 decreased $\mathrm{CH}_{4}$ growth rate and production in the fresh and memory solutions. Perfeldt et al. (2014) observed that the RmAFP1 changes from $\mathrm{CH}_{4}$ hydrate growth promoter in the fresh solution to inhibitor in the memory solution. However, mSA-RmAFP1 did not exhibit this change in our test. Histidine, tyrosine and lysine present similar growth rate and pressure drops $(12.78 \%, 12.75 \%$ and $13.49 \%$, respectively). Fig. 8 shows the hydrate growth curves for the memory solutions in the presence of mSA-RmAFP1 and PVP at different concentrations. It can be seen that the hydrate growth rate and pressure drop of $850 \mathrm{ppm}$ mSA-RmAFP1 is higher than $2250 \mathrm{ppm}$. The reason might be a higher concentration mSA-RmAFP1 could more effectively 
prevent $\mathrm{CH}_{4}$ hydrate growth. However, it was found that the hydrate growth rate and pressure drop of $2250 \mathrm{ppm}$ PVP was higher than $850 \mathrm{ppm}$. This indicated a higher concentration PVP can promote $\mathrm{CH}_{4}$ hydrate growth. As reported by Kumar et al. (2008), more $\left(\mathrm{CH}_{4}+\mathrm{C}_{3} \mathrm{H}_{8}\right)$ hydrates formed in the presence of $1.0 \mathrm{wt} \%$ PVP than low concentrations $(0.1-0.5 \mathrm{wt} \%)$.

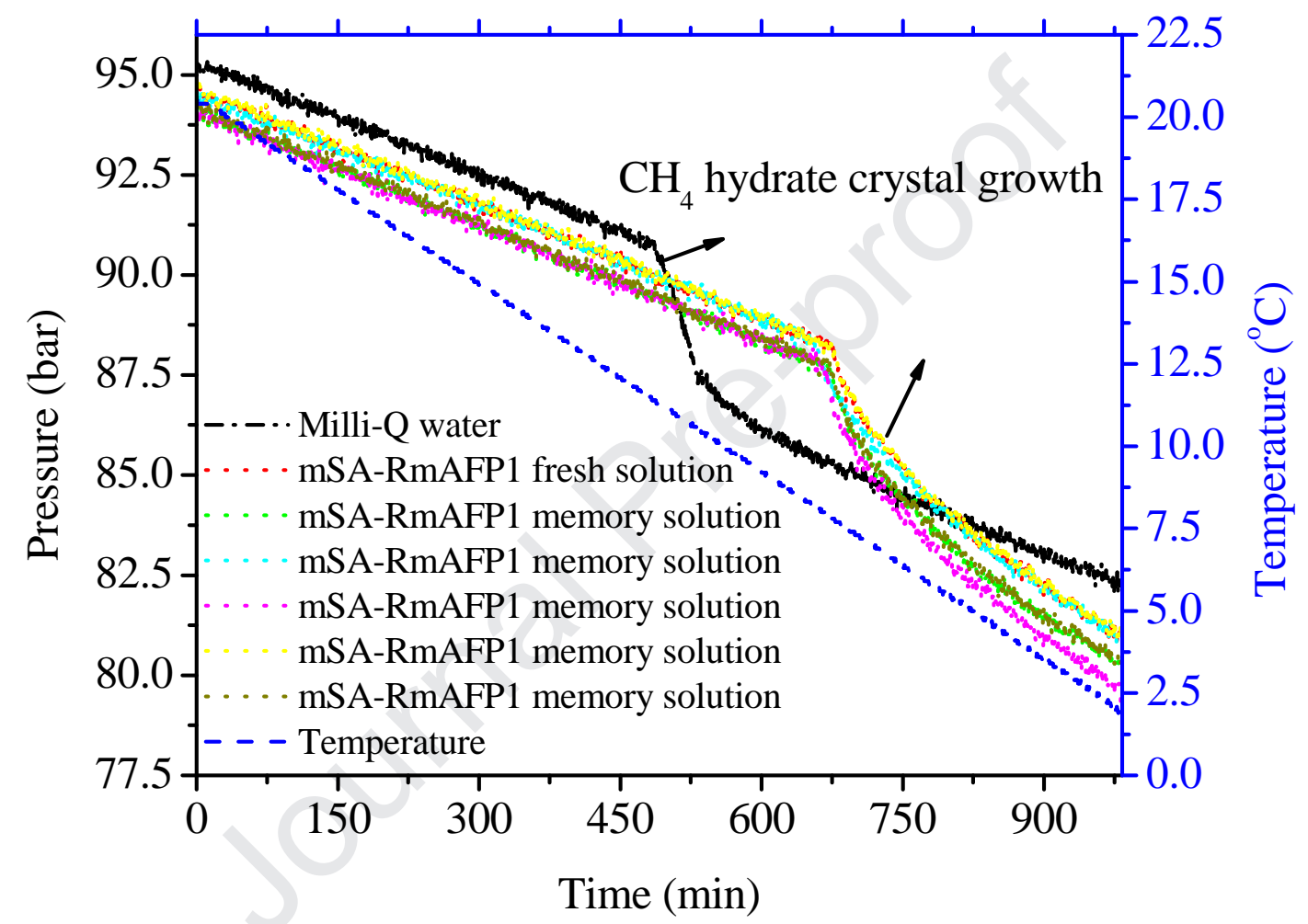

Fig. 5. Hydrate growth curves for the fresh and memory solutions containing $2250 \mathrm{ppm}$ mSA-RmAFP1. 


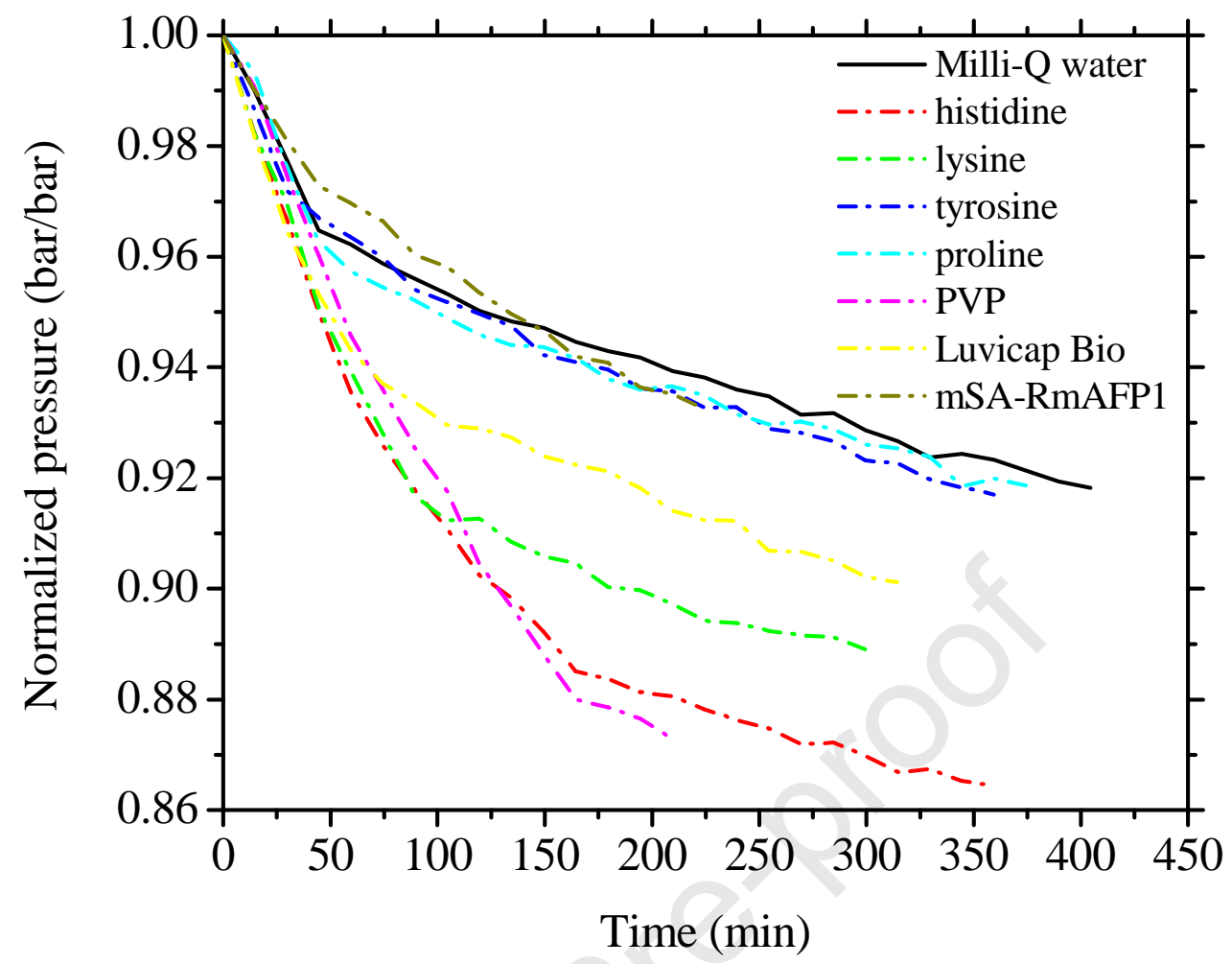

Fig. 6. Normalized hydrate growth curves for the fresh solutions containing $2250 \mathrm{ppm}$ inhibitors.

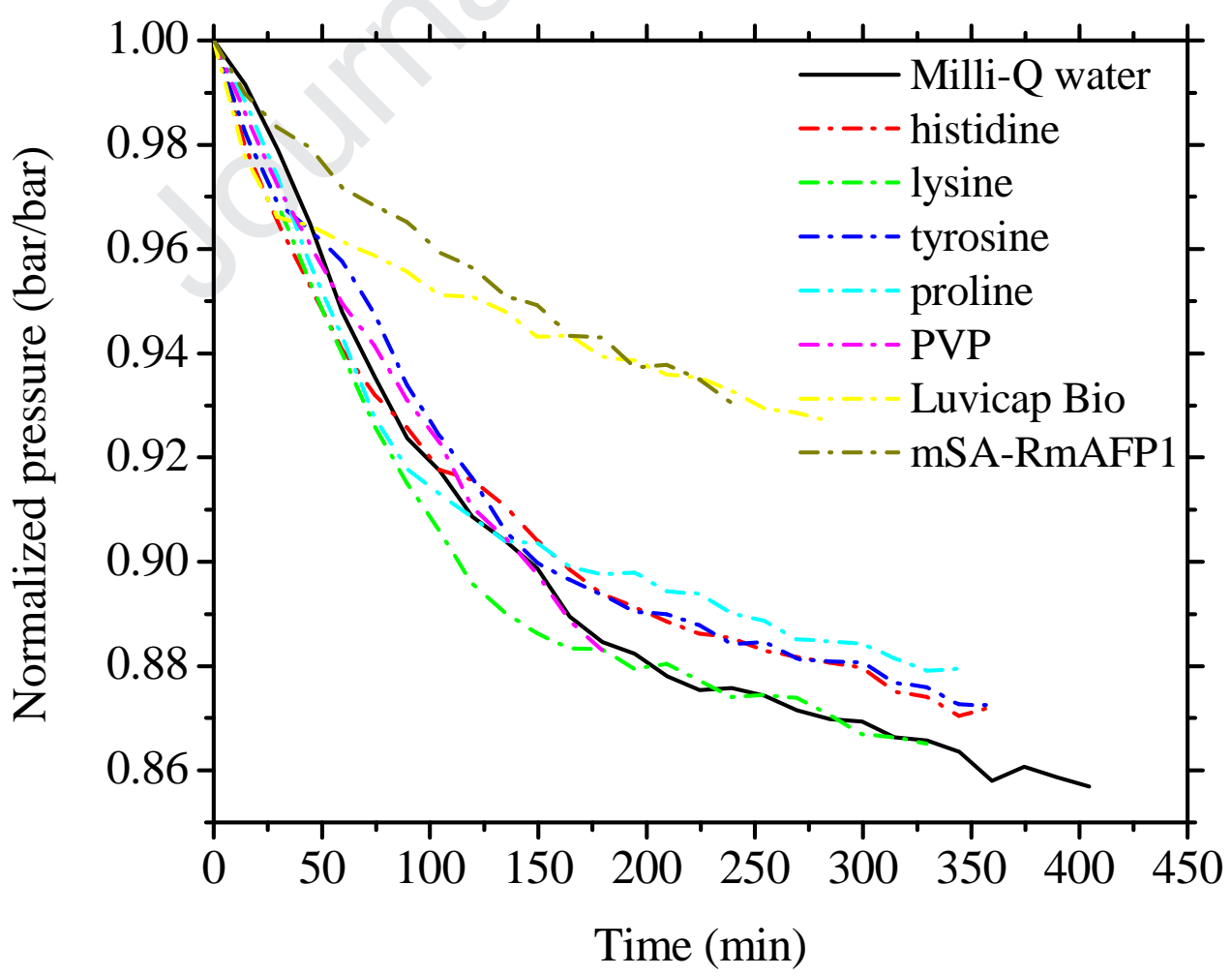

Fig. 7. Normalized hydrate growth curves for the memory solutions containing 2250 ppm inhibitors. 


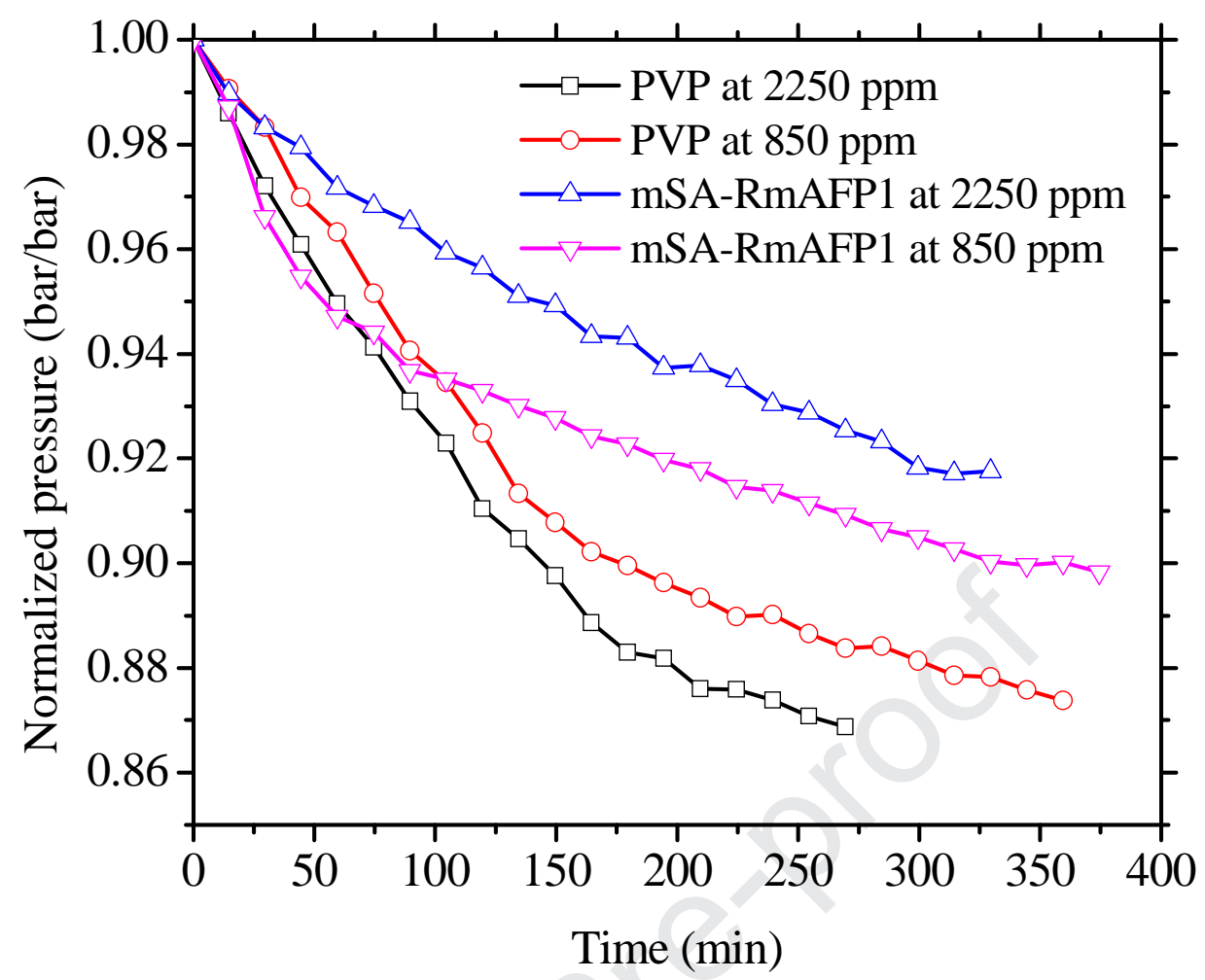

Fig. 8. Normalized hydrate growth curves for the mSA-RmAFP1 and PVP memory solutions.

\section{3. $\mathrm{CH}_{4}$ hydrate decomposition}

Hydrate formation is unavoidable in industry even in the case of existing various KHIs. Therefore, it is very important to understand the hydrate decomposition kinetics and predict decomposition rates. In this study, $\mathrm{CH}_{4}$ hydrate decomposition was tested to investigate if KHIs have impact on hydrate melting. The onset decomposition temperatures of $\mathrm{CH}_{4}$ hydrate in the fresh and memory solutions are shown in Figs. 9 and 10, respectively. The average onset hydrate decomposition temperatures for the fresh solutions follow the trend: 1, $2250 \mathrm{ppm}$ : mSA-RmAFP1 $\left(11.2^{\circ} \mathrm{C}\right)<\operatorname{PVP}\left(11.4{ }^{\circ} \mathrm{C}\right)<$ histidine $\left(11.5^{\circ} \mathrm{C}\right)<$ Luvicap Bio $\left(11.6^{\circ} \mathrm{C}\right)<$ lysine $\left(11.7{ }^{\circ} \mathrm{C}\right)<$ proline $\left(11.8{ }^{\circ} \mathrm{C}\right)=$ tyrosine $\left(11.8{ }^{\circ} \mathrm{C}\right)<\operatorname{Milli}-\mathrm{Q}$ water $\left(12.0{ }^{\circ} \mathrm{C}\right) ; 2,850$ ppm: mSA-RmAFP1 $\left(11.4{ }^{\circ} \mathrm{C}\right)<$ Luvicap Bio $\left(11.5{ }^{\circ} \mathrm{C}\right)<\operatorname{PVP}\left(11.6{ }^{\circ} \mathrm{C}\right)<\operatorname{Milli}-\mathrm{Q}$ water $\left(12.0{ }^{\circ} \mathrm{C}\right)$. It can be seen that the onset hydrate decomposition temperatures for the solutions containing various KHIs occurred slightly 
lower than the non-inhibited system. The hydrate decomposition recalcintrance was not observed under experimental conditions. Some researchers reported the KHIs can delay hydrate decomposition in their studies (Sharifi et al., 2014; Sharifi et al., 2016; Gulbrandsen and Svartås, 2017a,b). Sharifi et al. (2014) investigated the decomposition of natural gas hydrate $\left(\mathrm{CH}_{4} 93\right.$ $\left.\mathrm{mol} \%+\mathrm{C}_{2} \mathrm{H}_{6} 5 \mathrm{~mol} \%+\mathrm{C}_{3} \mathrm{H}_{8} 2 \mathrm{~mol} \%\right)$ in the presence of PVP (3.5 kDa) or PVCap (23.3 kDa) with stirred vessels and DSC apparatus. Their results showed that the KHIs increased hydrate decomposition temperature and prolong complete decomposition time. They believed that both sI and sII hydrtate formed in the presence of PVP and PVCap, then proposed a two-step decomposition mechanism. Subsequently, Sharifi et al. (2016) tested the impact of three KHIs (PVCap, AFP III and Luvicap Bio) on $\mathrm{C}_{3} \mathrm{H}_{8}$ hydrate decomposition with DSC apparatus. They found these KHIs has recalcitrance property for hydrate decomposition, and believed this property was not caused by the hydrate composition. Gulbrandsen and Svartås. (2017a,b) reported this unusual phenomenon on $\mathrm{CH}_{4}$ hydrate decomposition in the PVCap system in their recently studies. They observed that the concentration of PVCap and heating rate can affect the decomposition temperature. The hydrate decomposition behavior in the presence of KHIs was complicated, and it involves the types and concentrations of KHIs, heating rate, subcooling, dynamic or quiescent experimental conditions, etc. The comprehensive and systematic investigation need to be conducted before the KHIs application in the field. 


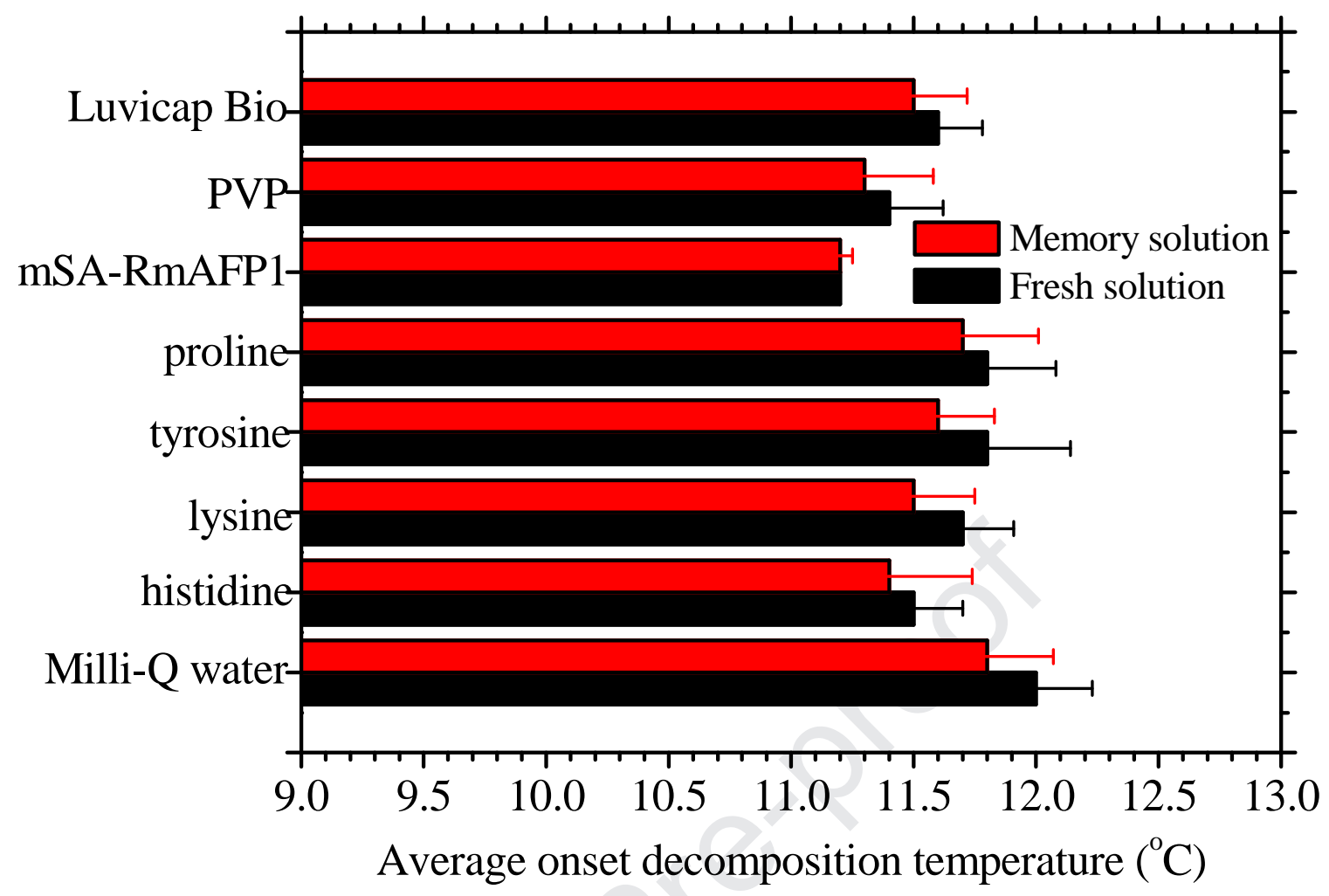

Fig. 9. The onset decomposition temperatures for the fresh and memory solutions containing $2250 \mathrm{ppm}$ inhibitors (error bars represent standard deviations).

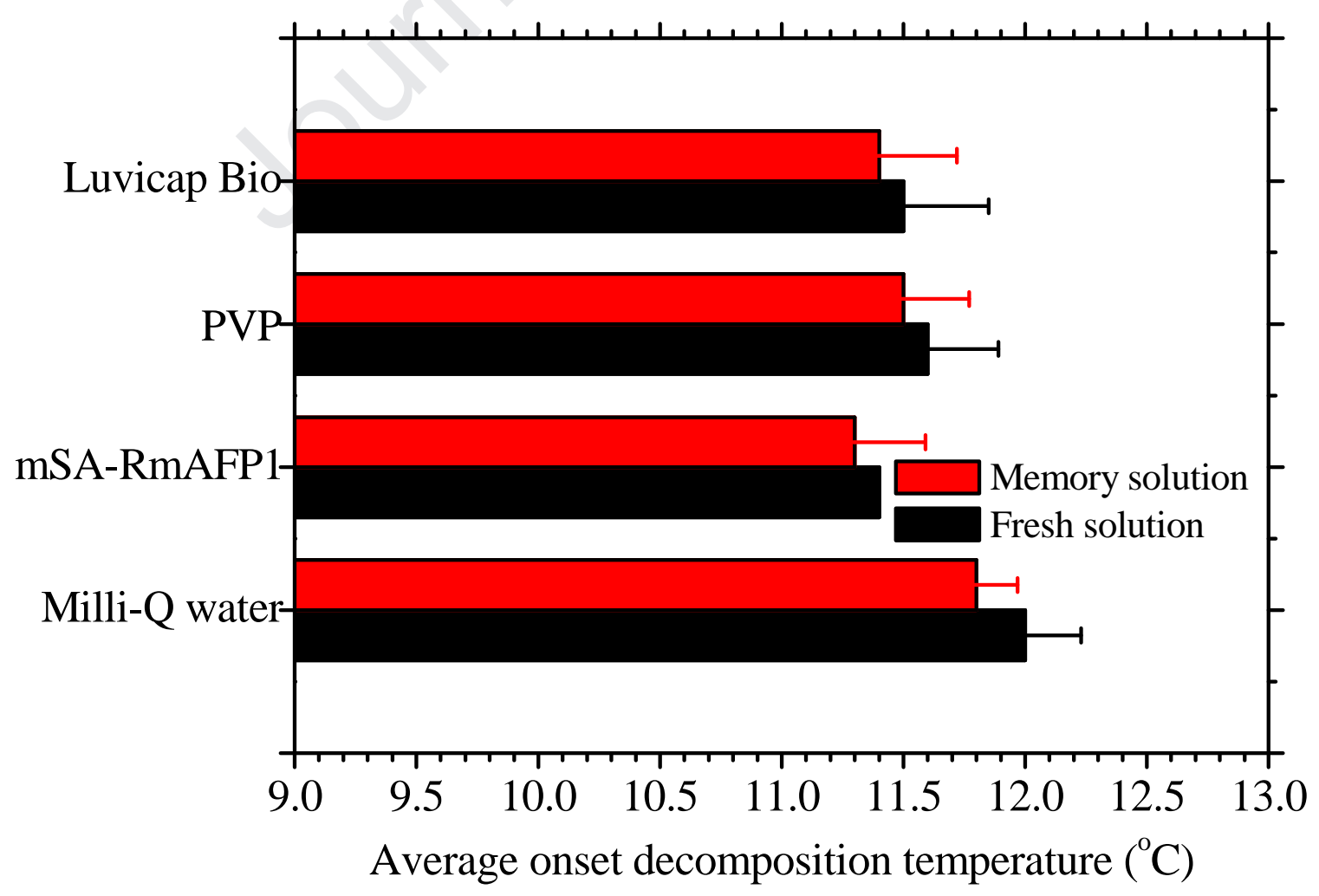


Fig. 10. The onset decomposition temperatures for the fresh and memory solutions containing $850 \mathrm{ppm}$ inhibitors (error bars represent standard deviations).

In order to compare the hydrate decomposition for different systems, pressure curves starting from the onset decomposition temperature are normalized. For the fresh solutions (Fig. 11), the Milli-Q water present the highest hydrate decomposition rate in the first $10 \mathrm{~min}$. The histidine and PVP systems showed longer complete decomposition time, the reason might be more hydrate formed in their solutions which need longer time to decompose. These observations are reasonable as it has been previously confirmed that hydrate samples prepared in the presence of inhibitors can increase the hydrate complete decomposition time (Lee and Englezos, 2006; Bruusgaard et al., 2009). In addition, the proline, tyrosine and mSA-RmAFP1 systems have low decomposition rate and short complete decomposition time. For the memory solutions (Fig. 12), the Luvicap Bio system showed the lowest hydrate decomposition rate, and the PVP system still present the longest complete decomposition time. From these results, it can be seen that $\mathrm{CH}_{4}$ hydrate formed by each solution can decompose completely within $40 \mathrm{~min}$. However, the hydrate decomposition curves are different depending on the type of inhibitors. Fig. 13 shows the normalized hydrate decomposition curves for mSA-RmAFP1 and PVP at different concentrations. It was found that the PVP concentration essentially have not effect on the decomposition rate. However, the pressure rise of 2250 ppm PVP was higher than that of 850 ppm PVP, which indicated more $\mathrm{CH}_{4}$ are released from the 2250 ppm PVP system. The 850 ppm mSA-RmAFP1 memory solution present a higher hydrate decomposition rate and pressure rise compared with $2250 \mathrm{ppm}$ solution. We speculated that the decomposition rate might be connected with hydrate production, the system with more amount of hydrate may have a higher decomposition rate. 


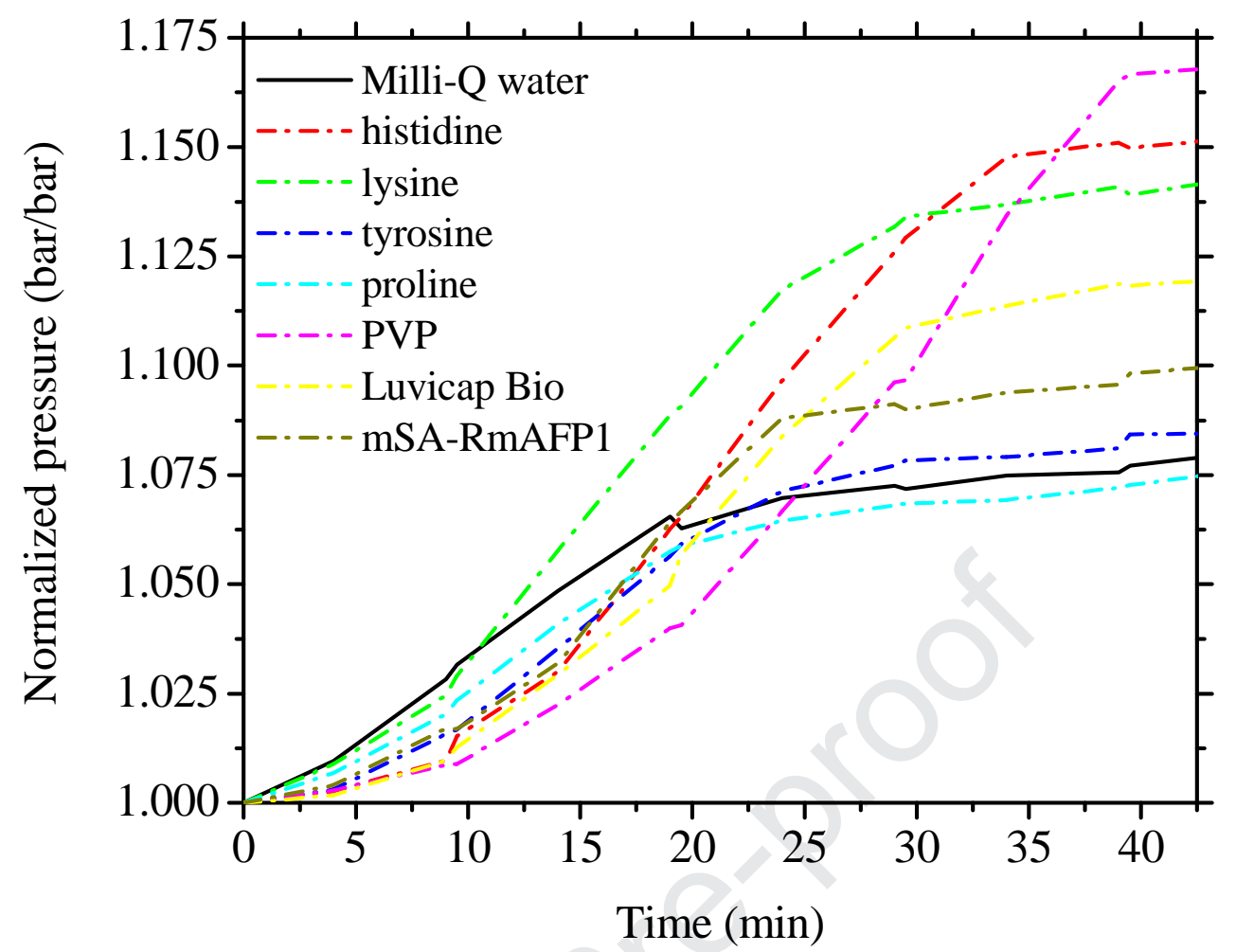

Fig. 11. Normalized hydrate dissociation curves for the fresh solutions containing $2250 \mathrm{ppm}$ inhibitors.

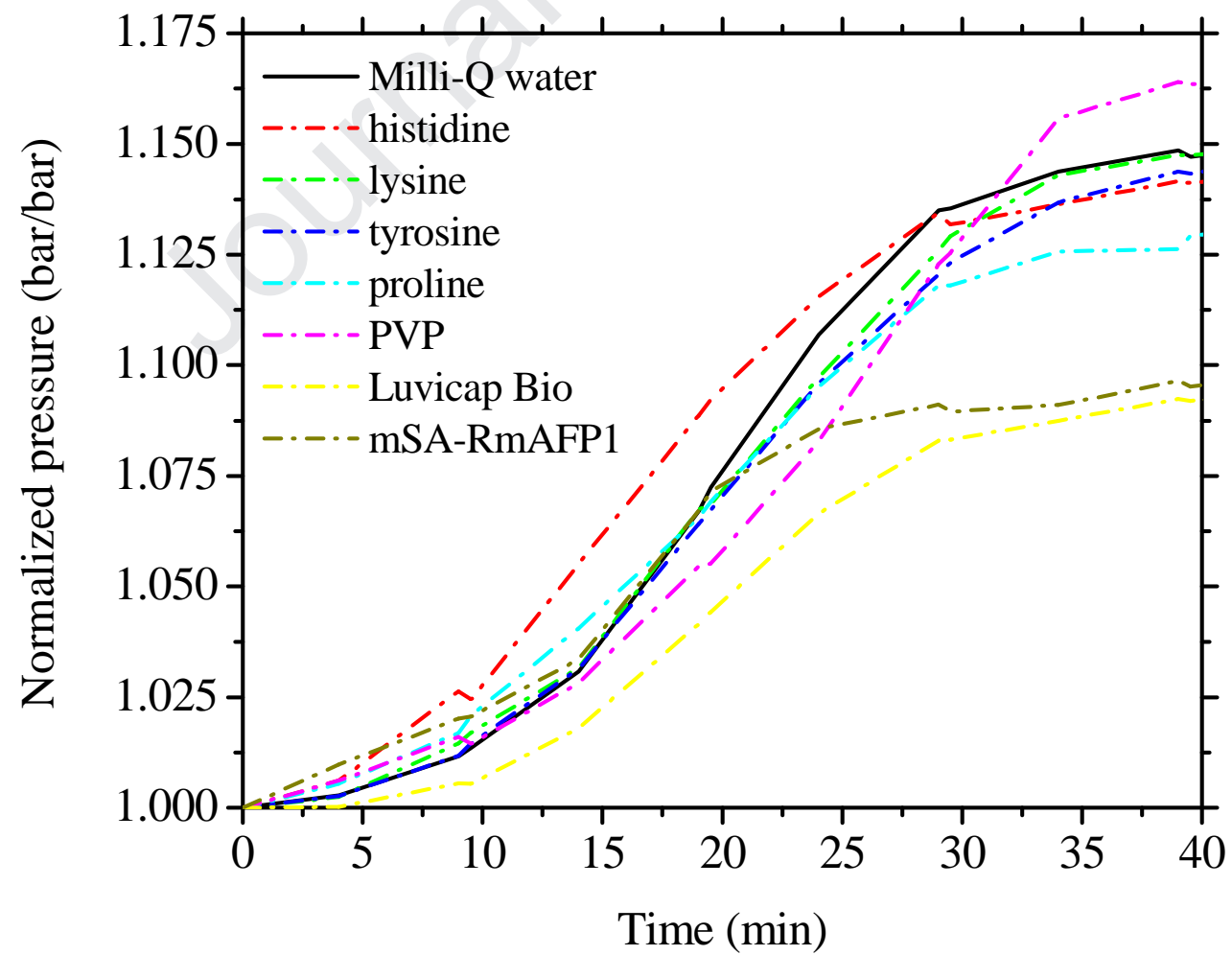

Fig. 12. Normalized hydrate dissociation curves for the memory solutions containing $2250 \mathrm{ppm}$ inhibitors. 


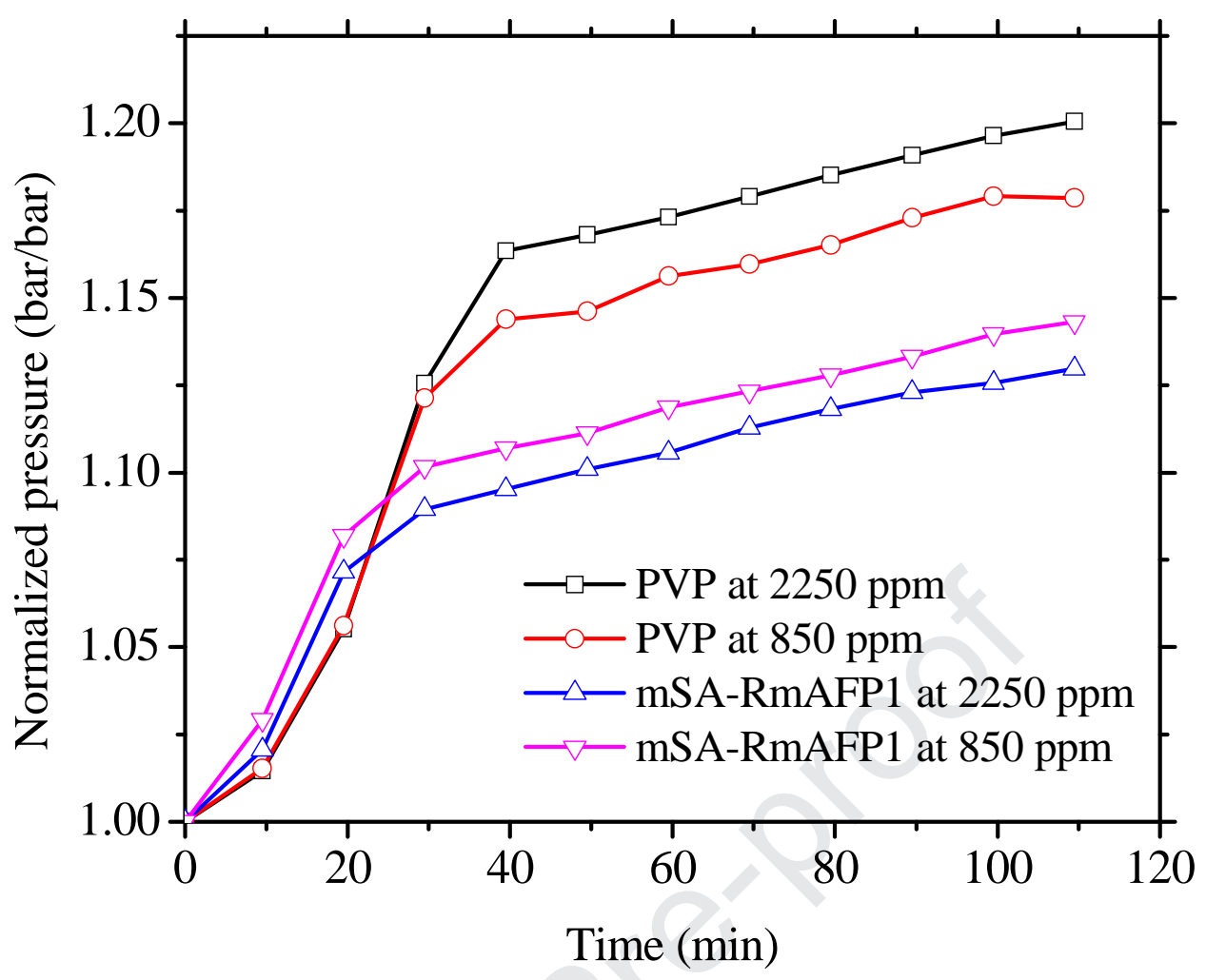

Fig. 13. Normalized hydrate decomposition curves for mSA-RmAFP1 and PVP memory solutions.

\subsection{The stability of $m S A-R m A F P 1$}

In order to investigate the stability of mSA-RmAFP1 solution, the onset hydrate nucleation and decomposition temperatures ( $T_{\text {on }}$ and $T_{\text {od }}$ ) for 2250 ppm mSA-RmAFP1 memory solutions were tested after several days. The results are shown in Fig. 14, the data at day zero is obtained from the first test using the fresh solution, then the mSA-RmAFP1 memory solution was kept at $4{ }^{\circ} \mathrm{C}$ for one or two weeks before further tests. It can be seen that the onset nucleation temperatures increased from 7.8 to 7.9 and $8.0{ }^{\circ} \mathrm{C}$ after 7 and 14 days, respectively. In addition, the onset decomposition temperatures increased from 11.2 to 11.3 and $11.3{ }^{\circ} \mathrm{C}$ after 7 and 14 days, respectively. The reason of these tiny changes in our results might be the memory effect of solutions. In previous study, Perfeldt et al. (2014) tested the stability of RmAFP1 in the memory solutions, they reported the onset nucleation temperatures increased from 8.6 to 9.3 and $9.9^{\circ} \mathrm{C}$ after 7 and 14 days, respectively. 
These results confirmed that the mSA-RmAFP1 has better stability than RmAFP1. The mSARmAFP1 is a known hyperactive AFP which was produced in a novel way by an insect cell line, whereas RmAFP1 was with a bacterial fermentation. The results are encouraging enough to pursue research in improving the AFP by genetic or other modifications (Friis et al., 2014; Kristiansen et al., 2012).

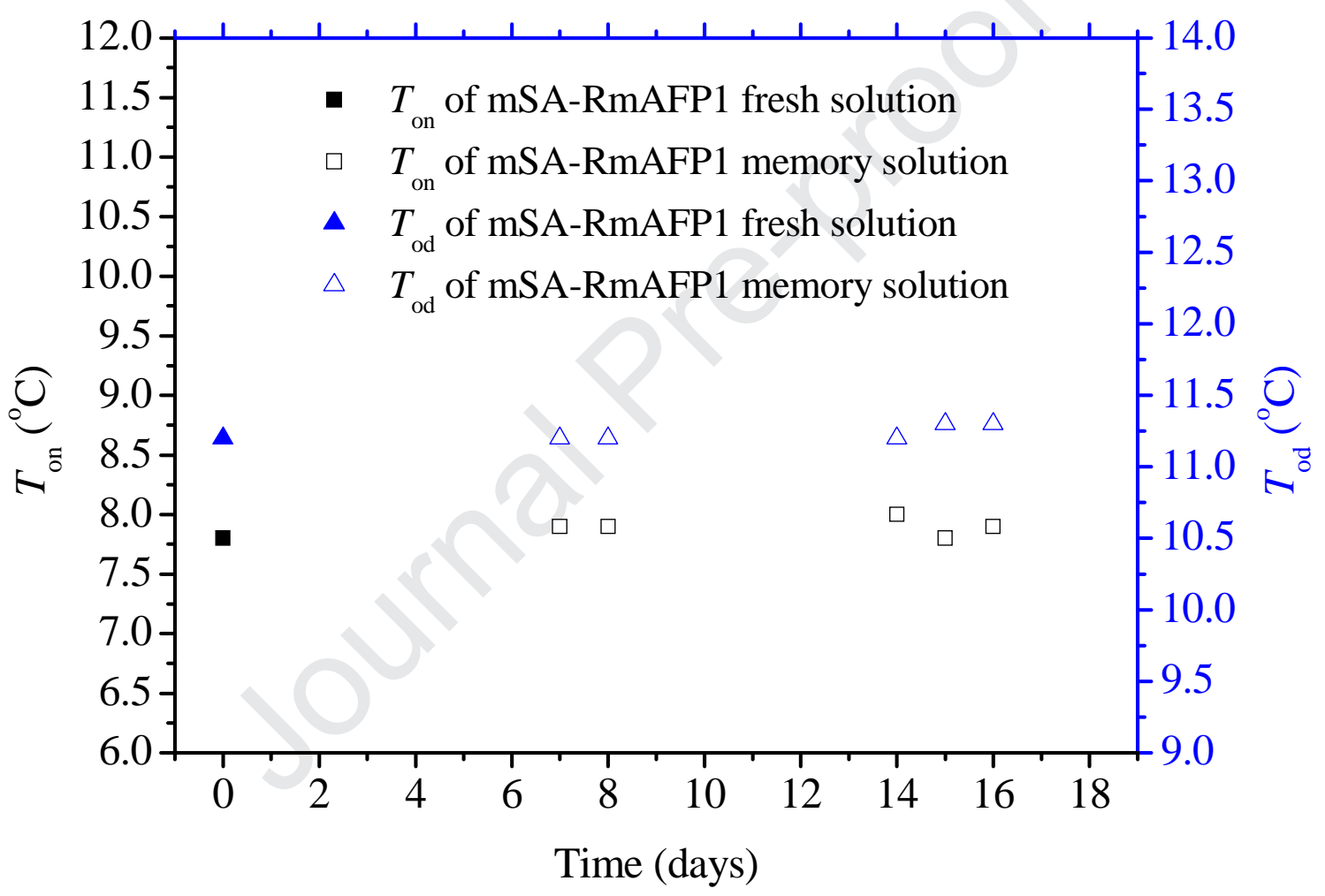

Fig. 14. Onset nucleation and decomposition temperatures for the fresh and memory solutions containing 2250 ppm mSA-RmAFP1.

\section{Conclusion}

The effectiveness of a new antifreeze protein (mSA-RmAFP1) on $\mathrm{CH}_{4}$ hydrate nucleation, growth and decomposition was investigated using the rocking cells apparatus, then compared with the synthetic inhibitors (PVP and Luvicap Bio) as well as the amino acids (histidine, lysine, tyrosine 
and proline). $\mathrm{CH}_{4}$ hydrate nucleation and growth exhibit good repeatable results under experimental conditions. The results showed that $2250 \mathrm{ppm}$ mSA-RmAFP1 decreased the onset hydrate nucleation temperature from 11.8 to $7.8{ }^{\circ} \mathrm{C}$, which was as effectively as PVP $\left(7.9^{\circ} \mathrm{C}\right)$ at the same concentration. Both the inhibition performance and stability of mSA-RmAFP1 are better than RmAFP1, which has been reported in our previously work. The amino acids (histidine, lysine, tyrosine and proline) present weak inhibition effect on $\mathrm{CH}_{4}$ hydrate nucleation. The mSA-RmAFP1 decreased $\mathrm{CH}_{4}$ hydrate growth rate and production in the fresh and memory solutions. The onset hydrate decomposition temperatures occurred slightly lower in the presence of the tested KHIs compared to the non-inhibited system under experimental conditions. The hydrate decomposition curves are different depending on the type of inhibitors. The promising performance of mSARmAFP1 suggests that it can be used as a kind of new green hydrate inhibitors. In any case AFPs are worth studying because their mechanism is clearly not the same as synthetic KHIs: As discussed in Sharifi et al. (2014), synthetic KHI's actually stabilize hydrates once formed whereas AFPs do not, making decomposition easier for AFP-containing hydrates. Furthermore, the successful production of AFPs through an insect cell line fermentation can help provide the basis for future production and optimization of these proteins for hydrate inhibition. In terms of environmental impact we can say the following: Proteins are not inherently "benign" (think spider and snake venom). However, while venom may be poisonous if injected into the blood stream, they are most certainly broken down in nature should they happen to be spilled somewhere outside the animals.

Concerning toxicity, tolerance level, inadvertent nutrition enrichment or over-enrichment of surrounding environment and half-life of the rate of bio-degradation, we can say that antifreeze proteins in general are considered non-toxic, we all have eaten fish which contain antifreeze proteins and the beetles in which Rm-AFP1 are found are not considered poisonous in any way, where they are consumed by a variety of birds. AFPs let out directly may contain a potentially 
significant amount of nitrogen, although nothing compared to what farmers burden the environment with, when fertilizing with various kinds of nitrogen-based fertilizers. In the laboratory AFPs do not last long if not frozen. Of course before any field applications are approved, they will still have to be subjected to the same tests as any other production chemicals (such as toxicity, tolerance level). Since proteins biodegrade into amino acids, effects such as inadvertent nutrition enrichment or over-enrichment of surrounding environment or bio-degradation are not expected for the amounts of protein needed as hydrate inhibitor - the sea is after all full of proteins and their degradation products.

\section{Acknowledgments}

Funding from the Ørsted-COFUND postdoc instrument, the Danish National Advanced Technology Foundation (BioRec project) and the Technical University of Denmark is acknowledged.

\section{References}

Al-Adel, S., Dick, J.A.G., El-Ghafari, R., Servio, P., 2008. The Effect of Biological and Polymeric Inhibitors on Methane Gas Hydrate Growth Kinetics. Fluid Phase Equilib. 267 (1), 92-98.

Bruusgaard, H., Lessard, L.D., Servio, P., 2009. Morphology Study of Structure I Methane Hydrate Formation and Decomposition of Water Droplets in the Presence of Biological and Polymeric Kinetic Inhibitors. Cryst. Growth Des. 9 (7), 3014-3023.

Buchanan, P., Soper, A.K., Thompson, H., Westacott, R.E., Creek, J.L., Hobson, G., Koh, C.A., 2005. Search for memory effects in methane hydrate: Structure of water before hydrate formation and after hydrate decomposition. J. Chem. Phys. 123, 164507-164514.

Bagherzadeh, S.A., Alavi, S., Ripmeester, J.A., Englezos, P., 2015. Why ice-binding type I 
antifreeze protein acts as a gas hydrate crystal inhibitor. Phys. Chem. Chem. Phys. 17 (15), 99849990.

Cohen, J.M., Wolf, P.F., Young, W.D., 1998. Enhanced hydrate inhibitors: powerful synergism with glycol ethers. Energy Fuels 12 (2), 216-218.

Daraboina, N., Linga, P., Ripmeester, J., Walker, V.K., Englezos, P., 2011a. Natural Gas Hydrate Formation and Decomposition in the Presence of Kinetic Inhibitors. 2. Stirred Reactor Experiments. Energy Fuels 25 (10), 4384-4391.

Daraboina, N., Malmos, C., von Solms, N., 2013b. Synergistic kinetic inhibition of natural gas hydrate formation. Fuel 108, 749-757.

Daraboina, N., Moudrakovski, I., Ripmeester, J.A., Walker, V.K., Englezos, P., 2013a. Assesing the Performance of Commercial and Biological Gas Hydrate Inhibitors Using Nuclear Magnetic Resonance Microscopy and a Stirred Autoclave. Fuel 105, 630-635.

Daraboina, N., Pachitsas, S., von Solms, N., 2013c. Experimental validation of kinetic inhibitor strength on natural gas hydrate nucleation. Fuel 139, 554-560.

Daraboina, N., Pachitsas, S., von Solms, N., 2013d. Natural gas hydrate formation and inhibition in gas/crude oil/aqueous systems. Fuel 148, 186-190.

Daraboina, N., Perfeldt, C.M., von Solms, N., 2015. Testing antifreeze protein from the longhorn beetle Rhagium mordax as a kinetic gas hydrate inhibitor using a high-pressure micro differential scanning calorimeter. Can. J. Chem. 93, 1025-1030. 
Daraboina, N., Ripmeester, J., Walker, V.K., Englezos, P., 2011b. Natural Gas Hydrate Formation and Decomposition in the Presence of Kinetic Inhibitors. 1. High Pressure Calorimetry. Energy Fuels 25 (10), 4392-4397.

Daraboina, N., Ripmeester, J., Walker, V.K., Englezos, P., 2011c. Natural Gas Hydrate Formation and Decomposition in the Presence of Kinetic Inhibitors. 3. Structural and Compositional Changes. Energy Fuels 25 (10), 4398-4404.

Demonte, D., Dundas, C., Park, S., 2014. Expression and purification of soluble monomeric streptavidin in Escherichia coli. Appl. Microbial. biotechnol. 98, 6285-6295.

Duchateau, C., Peytavy, J.L., Glénat, P., Pou, T.E., Hidalgo, M., Dicharry, C., 2009. Laboratory Evaluation of Kinetic Hydrate Inhibitors: A Procedure for Enhancing the Repeatability of Test Results. Energy Fuels 23 (2), 962-966.

Duman, J.G., Bennett, V., Sformo, T., Hochstrasser, R., Barnes, B.M., 2004. Antifreeze Proteins in Alaskan Insects and Spiders. J. Insect Physiol 50 (4), 259-266.

Duman, J.G.; Olsen, T.M., 1993. Thermal Hysteresis Protein Activity in Bacteria, Fungi, and Phylogenetically Diverse Plants. Cryobiology 30 (3), 322-328.

Duncum, S., Edwards, A.R., Lucy, A.R., Osborne, C.G., 1994a. Method for inhibiting solids formation and blends for use therein. WO Patent Application 94/24413.

Duncum, S., Edwards, A.R., Osborne, C.G., 1994b. Method for inhibiting hydrate formation. United States Patent: US5331105 (A).

Englezos, P., 1993. Clathrate hydrates. Ind. Eng. Chem. Res. 32, 1251-1274. 
Englezos, P., 1996. Nucleation and growth of gas hydrate crystals in relation to kinetic inhibition. Rev. Inst. Fr. Pet. 51 (6), 789-795.

Friis, D.S., Kristiansen, E., von Solms, N., Ramløv, H., 2014. Antifreeze activity enhancement by site directed mutagenesis on an antifreeze protein from the beetle Rhagium mordax. FEBS Letters $588(9), 1767-1772$.

Gulbrandsen, A.C., Svartås, T.M., 2017a. Effect of Poly Vinyl Caprolactam Concentration on the Dissociation Temperature for Methane Hydrates. Energy Fuels 31 (8), 8505-8511.

Gulbrandsen, A.C., Svartås, T.M., 2017b. Effects of PVCap on Gas Hydrate Dissociation Kinetics and the Thermodynamic Stability of the Hydrates. Energy Fuels 31 (9), 9863-9873.

Hammerschmidt, E.G., 1934. Formation of gas hydrates in natural gas transmission lines. Ind. Eng. Chem. $26(8), 851-855$.

Haymet, A.D.J., Ward, L.G., Harding, M.M., 1999. Winter Flounder "Antifreeze" Proteins: Synthesis and Ice Growth Inhibition of Analogues That Probe the Relative Importance of Hydrophobic and Hydrogen-Bonding Interactions. J. Am. Chem. Soc. 121 (5), 941-948.

Hjerrild, K.A., Jin, J., Wright, K.E., Brown, R.E., Marshall, J.M., Labbé, G.M., Silk, S.E., Cherry, C. J., Clemmensen, S.B., Jørgensen, T., Illingworth, J.J., Alanine, D.G.W., Milne, K.H, Ashfield, R., Jongh, W.A., Douglas, A.D., Higgins, M.K., Draper, S.J., 2016. Production of full-length soluble Plasmodium falciparum RH5 protein vaccine using a Drosophila melanogaster Schneider 2 stable cell line system. Sci. Rep. 6, 30357. Doi: 10.1038/srep30357.

Jensen, L., Ramlov, H., Thomsen, K., von Solms, N., 2010. Inhibition of Methane Hydrate Formation by Ice-Structuring Proteins. Ind. Eng. Chem. Res. 49 (4), 1486-1492. 
Jensen, L., Thomsen, K., von Solms, N., 2011. Inhibition of Structure I and II Gas Hydrates using Synthetic and Biological Kinetic Inhibitors. Energy Fuels 25, 17-23.

Kelland, M.A., 2006. History of the development of low dosage hydrate inhibitors. Energy Fuels 20 (3), 825-847.

Kelland, M.A., Mønig, K., Iversen, J.E., Lekvam, K., 2008. Feasibility Study for the Use of Kinetic Hydrate Inhibitors in Deep-Water Drilling Fluids. Energy Fuels 22 (4), 2405-2410.

Koh, C.A., 2002. Towards a fundamental understanding of natural gas hydrates. Chem. Soc. Rev. $31(3), 157-167$.

Koh, C.A., Westacott, R.E., Zhang, W., Hirachand, K., Creek, J.L., Soper, A.K., 2002. Mechanisms of gas hydrate formation and inhibition. Fluid Phase Equilib. 194, 143-151.

Kristiansen, E., Wilkens, C., Vincents, B., Friis, D., Lorentzen, A.B., Jenssen, H., Lobner-Olesen, A., Ramløv, H., 2012. Hyperactive Antifreeze Proteins from Longhorn Beetles: Some Structural Insights. J. Insect Physiol 58 (11), 1502-1510.

Kumar, R., Lee, J.D., Song, M., Englezos, P., 2008. Kinetic inhibitor effects on methane/propane clathrate hydrate-crystal growth at the gas/water and water/n-heptane interfaces. J. Cryst. Growth $310(6), 1154-1166$.

Lederhos, J.P., Long, J.P., Sum, A., Christiansen, R.L., Sloan, E.D., 1996. Effective kinetic inhibitors for natural gas hydrates. Chem. Eng. Sci. 51 (8), 1221-1229.

Lee, J. D., Englezos, P., 2006. Unusual kinetic inhibitor effects on gas hydrate formation. Chem. Eng. Sci. 61 (5), 1368-1376. 
May, E.F., Wu, R., Kelland, M.A., Aman, Z.M., Kozielski, K.A., Patrick, G.H., Nobuo, M., 2014. Quantitative kinetic inhibitor comparisons and memory effect measurements from hydrate formation probability distributions. Chem. Eng. Sci. 107, 1-12.

Ohno, H., Moudrakovski, I., Gordienko, R., Ripmeester, J., Walker, V.K., 2012, Structures of Hydrocarbon Hydrates during Formation with and without Inhibitors. J. Phys. Chem. A. 116 (5), 1337-1343.

Ohno, H., Susilo, R., Gordienko, R., Ripmeester, J., Walke, V.K., 2010. Interaction of Antifreeze Proteins with Hydrocarbon Hydrates. Chem. Eur. J. 16 (34), 10409-10417.

Perfeldt, C.M., Chua, P.C., Daraboina, N., Friis, D., Kristiansen, E., Ramløv, H., Woodley, J.M., Kelland, M.A., von Solms, N., 2014. Inhibition of Gas Hydrate Nucleation and Growth: Efficacy of an Antifreeze Protein from the Longhorn Beetle Rhagium mordax. Energy Fuels 28 (6), 3666-3672.

Perrin, A., Musa, O.M., Steed, J.W., 2013. The chemistry of low dosage clathrate hydrate inhibitors. Chem. Soc. Rev. 42, 1996-2015.

Raymond, J.A., Devries, A.L., 1977. Adsorption inhibition as a mechanism of freezing resistance in polar fishes. Proc. Nati. Acad. Sci. 74 (6), 2589-2593.

Sharifi, H., Ripmeester, J., Englezos, P., 2016. Recalcitrance of gas hydrate crystals formed in the presence of kinetic hydrate inhibitors. J. Nat. Gas Sci. Eng. 35, 1573-1578.

Sharifi, H., Ripmeester, J., Walker, V.K., Englezos, P., 2014. Kinetic inhibition of natural gas hydrates in saline solutions and heptane. Fuel 117, 109-117.

Sloan, E.D., Koh, C.A., 2008. Clathrate Hydrates of Natural Gases, third ed., CRC Press, Taylor \& Francis Group, New York. 
Villano, L.D., Kommedal, R., Kelland, M.A., 2008. Class of Kinetic Hydrate Inhibitors with Good Biodegradability. Energy Fuels 22 (5), 3143-3149.

Wilkens, C., Ramlov, H., 2008. Seasonal Variations in Antifreeze Protein Activity and Haemolymph Osmolality in Larvae of the Beetle Rhagium mMordax (Coleoptera: Cerambycidae). Cryoletters 29 (4), 293-300.

Yagasaki, T., Matsumoto, M., Tanaka, H., 2015. Adsorption Mechanism of Inhibitor and Guest Molecules on the Surface of Gas Hydrates. J. Am. Chem. Soc. 137 (37), 12079-12085.

Yagasaki, T., Matsumoto, M., Tanaka, H., 2018. Adsorption of Kinetic Hydrate Inhibitors on Growing Surfaces: A Molecular Dynamics Study. J. Phys. Chem. B. 122 (13), 3396-3406.

Yang, J., Tohidi, B., 2005. Characterization of inhibition mechanisms of kinetic hydrate inhibitors using ultrasonic test technique. Chem. Eng. Sci. 66 (3), 278-283.

Zeng, H., Moudrakovski, I.L., Ripmeester, J.A., Walker, V.K., 2006b. Effect of Antifreeze Protein on Nucleation, Growth and Memory of Gas Hydrates. AIChE J. 52 (9), 3304-3309.

Zeng, H., Wilson, L.D., Walker, V.K., Ripmeester, J.A., 2003. The inhibition of tetrahydrofuran clathrate-hydrate formation with antifreeze protein. Can. J. Phys. 81 (1-2), 17-24.

Zeng, H., Wilson, L.D., Walker, V.K., Ripmeester, J.A., 2006a. Effect of Antifreeze Proteins on the Nucleaton, Growth, and the Memory Effect during Tetrahydrofuran Clathrate Hydrate Formation. J. Am. Chem. Soc. 128 (9), 2844-2850. 


\section{Highlights}

- Hyperactive antifreeze protein synthesized by genetically modified insect cells

- The antifreeze protein was tested for sI hydrate inhibition in a rocking cell rig

- The protein was found to successfully inhibit hydrate formation

- Amino acids did not show efficacy for hydrate inhibtion 